\title{
THE CHARACTERISTICS OF FORENSIC AUDIT AND DIFFERENCES IN RELATION TO EXTERNAL AUDIT
}

\author{
Predrag Vukadinović ${ }^{\star}$, Goranka Knežević, Vule Mizdraković \\ Singidunum University, Faculty of Business in Belgrade, 32 Danijelova Street, Belgrade, Serbia
}

\begin{abstract}
:
Financial reporting is one of the most important factors affecting the overall business, in particular investment decision making. External audit aims to determine accuracy and objectivity of financial statements, i.e., disclosure of funds, resources and business performances in the financial statements, and to form an opinion based on the information provided. Therefore, the purpose of externaltraditional audit is not fraud detection that frequently appears in the background of an incorrect, unfair and unlawful presentation of financial statements. This has triggered the necessity to provide a new kind of auditing services that would be directed towards fraud prevention and detection. The answer to this need is the emergence of forensic audit, which differs from external audit in terms of its goals and character. There is no generally accepted definition of this concept, and the paper suggests differences in its definition and characteristics and differences in relation to external audit. The authors also attempt to point out to certain limitations that impede the development of a new audit discipline, which has justified its existence and indicated the necessity for its further development, both in theory and practice.
\end{abstract}

\author{
Key words: \\ external audit, \\ forensic audit, \\ fraud, \\ accounting.
}

\section{INTRODUCTION}

Business, financial and investment decisions must be based on true, exact and accurate financial reporting information in order to be correct and successful. The need of confirmation of the aforementioned characteristics of financial reporting outputs, from the viewpoint of external and internal users of financial statements and the needs of the decision-making process, has led to the emergence of auditing. Audit reports can have a strong impact on the business, financial and investment decisions, but also on the business reputation of the client who has hired the auditor. External audit has received strong theoretical and practical support, which is stressed out by numerous theoretical papers and research, but also a legal obligation of audit in relation to certain forms of legal entities. In this regard, besides the theoretical definition of audit showing certain consistency in accepting the basic elements of audit, there was also the legal definition.

Audit is processionally regulated by mandatory standards, but it should be noted that those same standards in certain cases prevent external audit to gain its full potential. This is particularly true in the case of fraud detection.

The expansion of major financial scandals, which usually as the background had scams and in the ever-growing number of frauds in previous decades, as well as the very substantial amounts of damages caused by frauds, has made an entrance for forensic audit, as well as other specialized audit services. When it comes to this type of audit, there is more information and knowledge from practice than from theory, and that is substantial difference in the conceptual, theoretical and practical perspective of this type of audit. The very nature of forensic audit stipulates differences in relation to external audit. These differences, resulting from different needs to which external audit cannot properly respond, are primarily related to prevention and detection of fraud with the elements of the offense, as well as preparation of relevant evidence for court proceedings. The restrictions that stand in the way of this type of audit are numerous. However, the main limitation is that the forensic audit is not mandatory, as in the case of external audit. The standards apply changes resulting from not so long practice. Historically, the demand for this type of service appeared sporadically, from case to case, and when the fraud is evident, it appeared as the subject of subsequent judicial proceedings. Only in the last few decades, especially after numerous financial scandals, the need for this audit service is becoming increasingly important. It is stressed out by all ever growing demand for this type of audit. Besides the lack of legal regulations and standards, the procedure itself is conducted by forensic auditors who must have special training and knowledge which is approved by license. In this sense, the process requires special training of experts on techniques and activities performed during court proceedings. All previously listed restrictions are not the only ones. There are more limits and new restrictions that arise from the practice and particular cases that are simultaneously reflected in the practice of forensic audit. 


\section{RESULTS AND DISCUSSION}

The users of financial statements are primarily interested in the accuracy, truthfulness and objectivity of data disclosed in financial statements. Business, financial and investment decision making processes are based inter alia on the above characteristics of disclosed data. Therefore, we can conclude that the financial reporting is an important factor in business, financial and investment decisions making processes. Investors are very interested in the financial condition and performance of companies that have investment as their goals. However, the financial statements do not always show the exact, true and objective data for a number of reasons. In certain cases, it may be the matter of accounting errors, oversights, ignorant or wrong application of International Accounting Standards (IAS). However, in some cases there may be a deliberate, false financial reporting resulting from a fraud with the elements of criminal activity. This phenomenon has triggered the emergence of a new form of detection, prevention and fight against fraud. In recent decades, the world's biggest financial scandals and the global financial damage, have led to the emergence of forensic audit.

As an example, one of the largest financial frauds and scandals in the financial markets, but also in the area of business ethics, is the company Enron, whose assets have nearly recorded ten-fold increase in only five years. To stand out (Schilit \& Pevler, 2010), the company recorded a growth in the period 1995-2000., i.e. for five years, from 9.2 billion US dollars to 100 billion US dollars. This growth has placed Enron in seventh place in terms of income among the top 500 companies ranked by Fortune magazine. It would be impossible to provide an answer to this serious question about this rapid growth without major acquisitions. It is well-known that this scandal-fraud went to trial. There are also some other cases of major financial scandals such as WorldCom Inc. company, Kmart Corp., etc. In addition to this scandal, according to Singleton et al. (2006), the Association of Certified Fraud Examiners (ACFE) stated 600 billion US dollars in losses in 2004 due to different ways of cheating. Overall, the fact that the number of frauds has increased in recent years, has motivated the companies to seek new directions and ways of combat with the activities with scams in their shadows. Forensic audit is one of the most important responses to this challenge.

In the literature, but in technical terms, according to Singleton et al. (2006) there is no clear demarcation of concepts of fraud audit, accounting investigations, forensic accounting, forensic auditors and so on, especially highlighting the conceptual differences between forensic accounting and forensic audit. Forensic audits or fraud audit as a synonyms aims primarily to specialized approach and methodology to recognize fraud and to provide a testimony. The same authors treated forensic accounting as a comprehensive approach in the investigation of fraud, which includes auditing of accounting records, in order to prove or disprove fraud. It also includes an interview with related parties which are related to the fraud and the role of forensic accountants as expert witnesses or expert in court.

A good description of differences in the definition of the term forensic audit gave (Silverstone et al., 2012), which stated that if you ask a question of two forensic auditor to define the forensic audit, you will get two different answers, which can be similar, but will not have the desired dimensions of consistency. Their replies will primarily depend on the practice and specialization in certain area of auditing. In an effort to highlight the consistency of different definitions, the authors point out that forensic audit focused primarily on deception, fraud prevention and investigation of fraud which would be its main role. This paragraph, therefore, recognizes the elements of generally accepted definition of forensic audit, but does not go beyond that.

Bearing in mind that the fraud was basically a criminal act, according to Hapwood et al. (2011), forensic accounting is the application of investigative and analytical skills to address financial issues in a way that will meet the required court standards. The terminology in the literature is often used as a synonym for the term "accountant", and as an accountant and auditor, as is the case in the definitions above. This is somewhat unclear use of the term, as a synonym provides mild confusion in the precise delimitation of the concepts of forensic auditors and forensic accountants, as already noted Singleton et al. (2006). Conceptual definition of forensic audit and forensic accounting extends to the conceptual definition of the perpetrators of this specialized auditing service. There is also no generally accepted definition of the term of forensic auditors, because different definitions are used both theoretically and terminologically. According to Singleton et al. (2006), fraud auditors must know what is fraud from the legal standpoint and standpoint of audit, then from the perspective of the business environment, fraud perpetrator, as well as from the cultural point of view. Also, fraud auditor must also have extensive experience in external audit, audit scams, but in particular, specific experience in various industries. Forensic accountants appear after the fraud auditors, where their significance lies in the fact that the complex financial transactions are "translated" so that they are understood and easily comprehended by anyone. This approach is necessary, bearing in mind that fraud ends in court, with the jury as non-experts. The scope of forensic accountants (Singleton et al., 2006) is wider than in the case of fraud auditors, because in addition to accounting and auditing they must be knowledgeable in the area of criminal investigation, conduct interviews, writing reports and testifying in court as an expert.

It is believed (Vukelić, 2014) that the development of forensic accounting and auditing is mostly affected by empirical knowledge acquired through business practices, while the theory in this case had a smaller impact. According to Petkovic (2011), an independent forensic audit is a new specialized service in external audit of financial statements. The same author states the definition of the Institute of Forensic Auditors (IFA), according to which the forensic audit is an activity of collecting, verifying, processing, analysing and reporting data in order to obtain facts and evidence that could be used in forensic financial disputes arising due to criminal activity.

Forensic audits are becoming more and more significant audit services. This specialized service that is separately arranged with the audit firms partly arose as a result of certain restrictions, but also the difference in essence and purpose of forensic and external audits. In addition to the above stated, the requirements for such a specialized service arose primarily from practice and less theory. 
Differences between external and forensic audit are reflected in several elements that can be said to represent a particular line of demarcation between the two auditing services. According to Grujic-Ojmjakon (2014), a thin line that separates forensic audit and external audit, is that forensic audit is a newly formed branch and has no generally accepted standards and does not differ significantly from external audit. According to the author, it would be more interesting to discuss about the development of audit in accordance with contemporary needs of business entities, with ever-growing participation of crime. However, a deeper analysis of the differences between these two types of audit services does not indicate that the differences are substantial and in some elements are very pronounced, depending on the character of these two audit services.

Differences in external audit and forensic audit can be observed from the aspect of differences in the definitions and characteristics of these two types of audit services. According to Stanisic (2008), audit can be defined as a systematic review of books and financial statements conducted by the auditor and experts to express a competent, professional and independent opinion on the validity, truthfulness and accuracy of the same. However, the legislation also defines audit (Audit Act, 2013) as the process of verification and evaluation of financial statements, as well as data and methods to be applied in preparing the financial statements on the basis of which an independent expert opinion is provided on whether the financial statements give a true and fair view of the financial position and results of operations of the legal entity in all material aspects and in accordance with the appropriate regulations for financial statement preparation. In addition to the audit, the Law (Law on Audit, 2013) allows auditing firms to provide additional services, besides mandatory audit, and that is where we should look for the traces of forensic audit.

Table 1 shows the distinction of external and forensic audit, which may be expressed through eleven elements which in a certain specific way reflect those differences: legislation, goals, constraints, materiality, duration of audit, methodology, investigation, report contents, court proceedings, fraud detection and obligations.

Table 1 . The differences between external and forensic audit
Elements of differences
External Audit
Forensic audit
1. Legislation
Legal and professional
Professional regulations

\section{Objective}

ness and accuracy of financial statements

3. Limitations

Limited by professional standards beyond which it does not perform further checks

Expression of professional, independent and competent opinion on the truthfulness, correctness and accuracy of financial statements
Prevention, investigation and detection of fraud

Not limited by external audit standards and can perform professional activities outside the standards

It is not important because it determines the amount of damage of the fraud regardless of the amount of damage

No specific timeline, activity lasts until the fraud is discovered

Investigate every financial transaction which is connected to fraud

One of the main activities

\section{Investigation}

Do not investigate

Provides independent, professional and com-

8. Reporting petent opinion in the form prescribed by the International Auditing Standards

\section{The court} proceedings

Expert auditor may be a witness in court

10. Method of detecting fraud

In the normal course and plan-review
Specialized report containing the elements of the offense of fraud and is intended for legal proceedings and there is no generally accepted standards prescribed

The forensic auditor is required as a witness in court in the role of expert
Mandatory process for medium and large sized entities in the Republic of Serbia, as well as for 11. Obligation public companies, regardless of their size and all legal entities or entrepreneurs with business turnover in the previous year amounted to more than 4.4 million euros

Alert, doubt, request the client and other ways

It is not a legal obligation 
External audit is increasingly becoming a separate service. In this context, developing various international associations and organizations that support forensic auditors, forensic audit and that in a certain way by formulating standards and other procedures governing the work of forensic auditors. The most famous associations are:

- Association of Certified Fraud Examiners (ACFE);

- American College of Forensic Examiners (ACFE);

- Association of Certified Fraud Specialist (ACFS);

- Institute of Forensic Auditors (IFA).

In addition to these global associations and organizations, some other similar associations and organizations were formed. However, forensic audit is not a legal obligation, but may also be made periodically to the client's request, as well as regular checks, based on internal or external alarm, doubt or for other reasons. Therefore, there is no legislation that would make this activity mandatory, so it is a matter of possible and special needs of the company. The growing number of frauds and the amount of damages due to fraud represent the proof that this type of audit should gain some form of legal obligation, as is the case of external audit.

\section{SUMMARY}

Despite certain differences in various definitions of forensic audit, considering that the audit theory has not provided a unique response in terms of defining the audit services, one of the elements is still common in nearly all definitions. That is the focus of forensic audit on the prevention, investigation and detection of fraud and the term fraud is a term that is included in almost all theoretical efforts to define forensic audit. However, fraud is not the only term used to define these auditing services, but it represents the essence of any definition while other terms in the theoretical sense have primarily practical application. Conceptual and theoretical differences in the definition of external and forensic audit, resulting from the character or nature of the two audit services, which mostly originate from the practice rather than from theoretical approaches and from attempts to define the term forensic audit. In particular, by relying on both theory and practice, eleven elements could be differentiated. They show the difference between external and forensic audit. It cannot be claimed that those are the only differences, as the practice and theory progress over time and point out to other differences. The restrictions that stand in the way of development and involvement of forensic audit into practice in terms of commitment are primarily legal in nature. Bearing in mind that this type of audit is still developing through practice, the limitations arising from the nature of forensic audit are very important for the decision-making process. Also, the theory, which attempts to define forensic audit, have encountered certain issues, mainly due to the emergence of new limitations. On the other hand, the theory will get better chance in defining the concept and providing new directions for development, because of the constant progress of forensic audit.

\section{REFERENCES}

Grujić-Kalakan, M. (2012). Forenzička revizija u funkciji otkrivanja kriminalnih radnji. Financing, 02/12, 31-38.

Hopwood, W. S., Leiner, J. J., \& Young, G. R.(2011). Forensic Accounting and Fraud Examination. New York: McGraw-Hill.

Petković, A. (2011). Šta je forenzičko računovodstvo?. U: Finansijsko izveštavanje u funkciji unapređenja poslovnog ambijenta u Crnoj Gori, 20-22.2011. (str. 93-107). Bečići: Institut sertifikovanih računovođa Crne Gore.

Schilit, H.M., \& Perler, J. (2010). How to detect accounting gimmicks \& fraud in financial reports. New York: McGrow-Hill.

Silverstone, H., Sheetz, M., Pedneault, S., \& Rudewicz, F. (2012). Forensic Accounting and for Non-Experts. Hoboken, NJ: John Wiley \& Sons.

Singleton, T., Singleton, A., Bologna, J., \& Lindquist, R. (2006). Fraud Auditing and Forensic Accounting. Haboken, NJ: John Wiley \& Sons.

Službeni glasnik RS. (2013). Zakon o reviziji. Službeni glasnik Republike Srbije, br. 62/2013.

Stanišić, M. (2008). Revizija. Beograd: Univerzitet Singidunum.

Vukelić G. (2014). Prevare i forenzika. U: Konferencija o bezbednosti informacija BISEC 2014. 18.06.2014. (str. 47-53). Beograd: Univerzitet Metropolitan.

\section{KARAKTERISTIKE FORENZIČKE REVIZIJE I RAZLIKE U ODNOSU NA EKSTERNU REVIZIJU}

\section{Apstrakt:}

Finansijsko izveštavanje predstavlja jedan od najznačajnijih segmenata poslovnog, a naročito investicionog odlučivanja. Eksterna revizija ima za cilj da utvrdi tačnost i objektivnost finansijskih izveštaja, odnosno prikazivanja sredstava, izvora sredstava i uspešnost poslovanja koje prikazuju finansijski izveštaji, i da na osnovu toga formira mišljenje.

Cilj eksterne-tradicionalne revizije nije otkrivanje prevara koje se često javljaju usled netačnog, neobjektivnog i nezakonitog prikazivanja informacija u finansijskim izveštajima. Stoga je neophodno da se oformi nova vrsta revizijske usluge koja će imati za cilj upravo preventivu i otkrivanje prevara. Odgovor na to jeste forenzička revizija koja se po cilju i karakteru razlikuje od eksterne revizije. Ovaj pojam nema opšteprihvaćenu definiciju, te rad ukazuje na različitosti u njegovom definisanju, razlike u odnosu na eksternu reviziju, kao i određena ograničenja koja otežavaju razvoj jedne nove discipline revizije, discipline koja je do sada opravdala svoje postojanje, i koja se mora dalje razvijati kako u teoriji tako i u praksi.

\section{Ključne reči:}

eksterna revizija,

forenzička revizija,

prevara,

računovodstvo. 